Keywords: $M S T$, $m M S T$, SCIX, Strontium, Actinides

Retention: Permanent

\title{
Strontium and Actinide Sorption by MST and mMST Under Conditions Relevant to the Small Column Ion- Exchange (SCIX) Process
}

K. M. L. Taylor-Pashow

D. T. Hobbs

M. R. Poirier

April 2011

Savannah River National Laboratory

Savannah River Nuclear Solutions, LLC Aiken, SC 29808

Prepared for the U.S. Department of Energy under contract number DE-AC09-08SR22470.

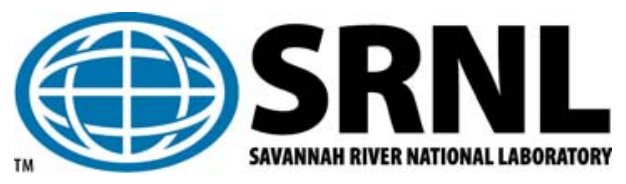


SRNL-STI-2011-00215

Revision 0

\section{DISCLAIMER}

This work was prepared under an agreement with and funded by the U.S. Government. Neither the U.S. Government or its employees, nor any of its contractors, subcontractors or their employees, makes any express or implied:

1. warranty or assumes any legal liability for the accuracy, completeness, or for the use or results of such use of any information, product, or process disclosed; or

2. representation that such use or results of such use would not infringe privately owned rights; or

3. endorsement or recommendation of any specifically identified commercial product, process, or service.

Any views and opinions of authors expressed in this work do not necessarily state or reflect those of the United States Government, or its contractors, or subcontractors.

\section{Printed in the United States of America \\ Prepared for \\ U.S. Department of Energy}




\section{REVIEWS AND APPROVALS}

AUTHORS:

K. M. L. Taylor-Pashow, Separations and Actinide Science Programs

Date

D. T. Hobbs, Separations and Actinide Science Programs

Date

M. R. Poirier, Advanced Characterization and Processing

Date

TECHNICAL REVIEW:

T. B. Peters, Separations and Actinide Science Programs

Date

APPROVAL:

S. D. Fink, Manager

Date

Separations and Actinide Science Programs

Date

S. L. Marra, Manager

Environmental \& Chemical Process Technology Research Programs

T. H. Huff, Manager

Date

Small Column Ion Exchange Engineering 


\section{EXECUTIVE SUMMARY}

A series of tests were performed to examine the kinetics of $\mathrm{Sr}$ and actinide removal by monosodium titanate (MST) and modified monosodium titanate (mMST) under mixing conditions similar to what will be provided in the Small Column Ion Exchange (SCIX) Program. Similar removal kinetics were seen for two different mixing energies, indicating that under these conditions bulk solution transport is not the rate limiting step for $\mathrm{Sr}$ and actinide removal. $\mathrm{Sr}$ removal was found to be rapid for both MST and mMST, reaching steady-state conditions within six hours. In contrast, at least six weeks is necessary to reach steady-state conditions for Pu with MST. For mMST, steady-state conditions for Pu were achieved within two weeks. The actual contact time required for the SCIX process will depend on starting sorbate concentrations as well as the requirements for the decontaminated salt solution. During testing leaks occurred in both the MST and mMST tests and evidence of potential desorption was observed. The desorption likely occurred as a result of the change in solids to liquid phase ratio that occurred due to the loss of solution. Based on these results, Savannah River National Laboratory (SRNL) recommended additional testing to further study the effect of changing phase ratios on desorption. This testing is currently in progress and results will be documented in a separate report. 


\section{TABLE OF CONTENTS}

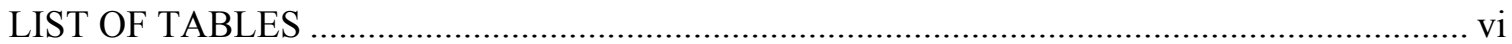

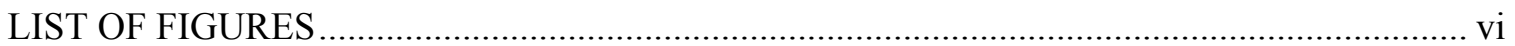

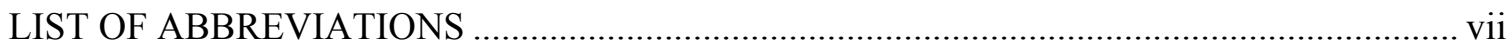

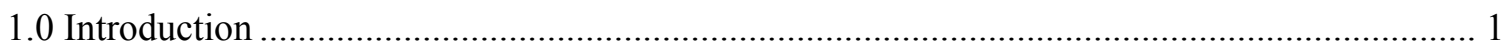

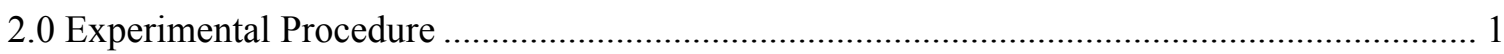

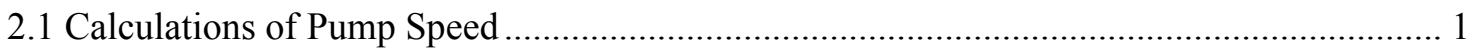

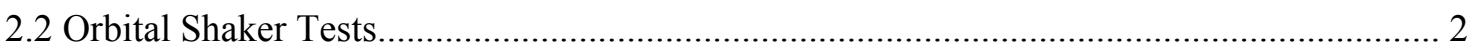

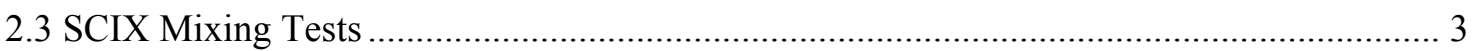

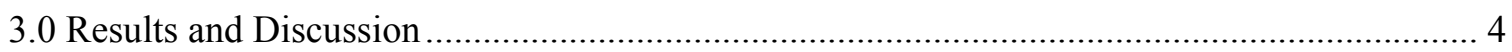

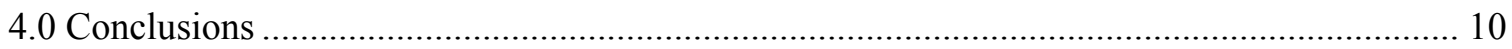

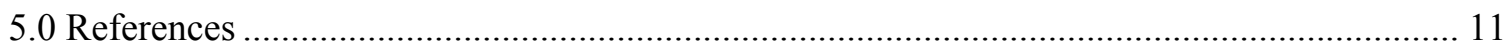

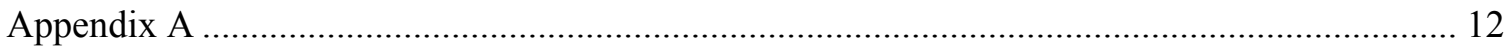




\section{LIST OF TABLES}

Table 2-1. Composition of SWS-5-2010.

Table 3-1. Summary of ${ }^{85} \mathrm{Sr}$ Decontamination Factors (DF). The uncertainty (Unc.) column represents one sigma uncertainty. The shaded boxes indicate data points taken after the leak was discovered.

Table 3-2. Summary of Pu Decontamination Factors (DF). The uncertainty (Unc.) column represents one sigma uncertainty. The shaded boxes indicate data points taken after the leak was discovered.

Table 3-3. Summary of Np Decontamination Factors (DF). The uncertainty (Unc.) column represents one sigma uncertainty. The shaded boxes indicate data points taken after the leak was discovered.

Table 3-4. Summary of ${ }^{238} U$ Decontamination Factors (DF). The uncertainty (Unc.) column represents one sigma uncertainty. The shaded boxes indicate data points taken after the leak was discovered.

\section{LIST OF FIGURES}

Figure 1. Photo of SCIX mixing test vessel.

Figure 2. ${ }^{85} \mathrm{Sr}$ activity versus contact time for the first week of testing. Open data points identify maximum concentrations (i.e., measured concentrations are at detection limits).

Figure $3 .{ }^{85} \mathrm{Sr}$ activity versus contact time. Open data points identify maximum concentrations (i.e., measured concentrations are at detection limits).

Figure 4. Total Pu concentration (from PuTTA data) versus contact time. Open data points identify maximum concentrations (i.e., measured concentrations are at detection limits). ..... 6

Figure 5. ${ }^{237} \mathrm{~Np}$ concentration (from ICP-MS data) versus contact time. Open data points identify maximum concentrations (i.e., measured concentrations are at detection limits).................. 7

Figure 6. ${ }^{238} \mathrm{U}$ concentration (from ICP-MS data) versus contact time. ....................................... 7

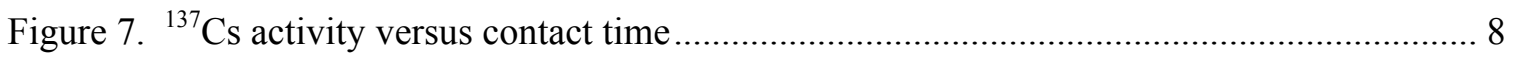

Figure A-1. Sr-85 DF versus contact time. Open data points indicate minimum DF values. ......12

Figure A-2. Pu DF versus contact time. Open data points indicate minimum DF values ............12

Figure A-3. Np DF versus contact time. Open data points indicate minimum DF values ...........13

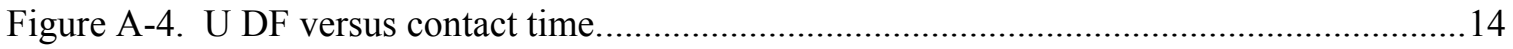




\section{LIST OF ABBREVIATIONS}

$\begin{array}{ll}\text { CST } & \text { crystalline silicotitanate } \\ \text { DF } & \text { decontamination factor } \\ \text { DWPF } & \text { Defense Waste Processing Facility } \\ \text { ICP-MS } & \text { inductively coupled plasma - mass spectroscopy } \\ \text { MSP } & \text { Modular Salt Processing } \\ \text { MST } & \text { monosodium titanate } \\ \text { mMST } & \text { modified monosodium titanate } \\ \text { PuTTA } & \text { plutonium thenoyltrifluoroacetone scintillation } \\ \text { PVDF } & \text { polyvinylidene fluoride } \\ \text { SCIX } & \text { small column ion exchange } \\ \text { SMP } & \text { submersible mixer pump } \\ \text { SRNL } & \text { Savannah River National Laboratory } \\ \text { SRR } & \text { Savannah River Remediation } \\ \text { SWPF } & \text { Salt Waste Processing Facility } \\ \text { TTQAP } & \text { Task Technical and Quality Assurance Plan }\end{array}$




\subsection{Introduction}

The Small Column Ion Exchange (SCIX) Program (formerly referred to as the Modular Salt Processing (MSP) Project) seeks to deploy equipment to remove the Cs, Sr, and select actinides from the high level waste salt solutions using existing waste tanks for the shielding. The process will involve adding monosodium titanate (MST) to the waste tank (i.e., Tank $41 \mathrm{H}$ ) to sorb the $\mathrm{Sr}$ and select actinides, removing the MST and entrained sludge with an in-riser rotary microfilter, and subsequently using ion-exchange columns containing crystalline silicotitanate (CST) to remove the Cs. After being loaded with Cs, the CST will be ground to reduce its size and will then be transferred into a waste tank (e.g., Tank 40H). The MST and sludge solids stream will be transported to a sludge batch preparation tank (i.e., Tank $42 \mathrm{H}$ or Tank $51 \mathrm{H}$ ) once the SCIX batch is processed. Both streams, MST/solids and CST, will ultimately be transported to the Defense Waste Processing Facility (DWPF).

The SCIX Program will perform the MST strike for Sr and actinide sorption in a Type III waste tank rather than the current approach using a process tank located at $241-96 \mathrm{H}$. Mixing of the solids and liquids will be more difficult in the waste tank for the following reasons: the waste tank is much larger, the waste tank contains cooling coils that obstruct the flow path of the jets created by the mixing pumps, and the tank is mixed by pumps rather than an impeller. Effective solid-liquid mixing and solid resuspension is critical for the successful implementation of the SCIX Program.

Previous testing on rates of sorbate removal by MST indicated that factors such as initial sorbate concentrations, ionic strength, and MST concentration have the greatest impact on sorbate removal rates. ${ }^{1}$ The lack of significant influence of mixing and mixing intensity on sorbate removal rates indicated that bulk solution transport is not the rate controlling step in the removal of $\mathrm{Sr}$ and actinides over the range of conditions and laboratory scales tested to date. However, bulk solution transport may become a significant parameter upon use of MST in a 1.3 milliongallon waste tank such as that planned for the SCIX Program. ${ }^{1}$ To evaluate the kinetics of Sr and actinide removal under conditions relevant to SCIX, a series of $\mathrm{Sr}$ and actinide sorption studies were performed with both MST and modified MST (mMST) to determine if mixing intensity influences the sorption rate.

Tests were performed at a 3 -L scale using a peristaltic pump to provide the mixing. The pump tubing diameter and speed were scaled to provide the same mixing energy per unit volume as two submersible mixer pumps (SMP) operating in a 1.3 million-gallon waste tank. Testing was completed using the two SMPs equivalent as these tests were started before the pilot-scale testing indicated three SMPs would likely be necessary.

This work was performed at the request of the SCIX Engineering group of Savannah River Remediation $(\mathrm{SRR})^{2}$ and was controlled by a Task Technical and Quality Assurance Plan (TTQAP). ${ }^{3}$

\subsection{Experimental Procedure}

\subsection{Calculations of Pump Speed}

Calculations were performed to determine the power per unit volume supplied by two SMPs operating in a 1.3 million-gallon waste tank. A pump speed was then calculated for a peristaltic pump to provide the same mixing energy for $3 \mathrm{~L}$ of simulant. It was determined that a flow rate of 2.09 gallons per minute through 0.375 inch diameter tubing would provide the same power per 
unit volume for $3 \mathrm{~L}$ as two SMPs would provide in a 1.3 million-gallon waste tank. Details of the calculations can be found in the Appendix.

\subsection{Simulant Preparation}

The composition for the simulant to be used in this testing was agreed upon between SRNL and SRR personnel. The chemical composition is based upon the simulant developed for solvent extraction testing, with some simplifications. ${ }^{4}$ Trace salts were omitted as their presence was previously shown not to effect the sorption properties of MST. ${ }^{5}$ The actinide concentrations are consistent with the simulant used for previous MST testing. The Pu concentration of $0.2 \mathrm{mg} / \mathrm{L}$ bounds the $\mathrm{Pu}$ concentration in 6 out of 7 of the tanks selected as bounding for the Salt Waste Processing Facility (SWPF) (i.e. $13 \mathrm{H}, 30 \mathrm{H}, 37 \mathrm{H}, 39 \mathrm{H}, 45 \mathrm{~F}, 46 \mathrm{~F}$, and $49 \mathrm{H}){ }^{6}$ Tank $39 \mathrm{H}$ had a measured soluble $\mathrm{Pu}$ content of $1.13 \mathrm{mg} / \mathrm{L}$; however, the next highest measured $\mathrm{Pu}$ concentration was $0.0081 \mathrm{mg} / \mathrm{L}$ (Tank $37 \mathrm{H})$. The $\mathrm{U}$ and $\mathrm{Np}$ concentrations of 10 and $0.5 \mathrm{mg} / \mathrm{L}$, respectively, bound all 7 of the previously mentioned tanks. The total $\mathrm{Sr}$ concentration is based upon the average Sr concentration measured in the 7 tanks. The target $\mathrm{Sr}$ concentration is $6 \mathrm{mg} / \mathrm{L}$; however, this concentration may not be achieved due to the elevated carbonate concentration in this simulant. This simulant was filtered before use to remove insoluble $\mathrm{Sr}$ and the soluble $\mathrm{Sr}$ concentration was measured. The composition of the simulant is provided in Table 2-1.

Table 2-1. Composition of SWS-5-2010.

\begin{tabular}{|c|c|c|}
\hline Component & Target Concentration & Measured Concentration \\
\hline $\mathrm{NaNO}_{3}$ & $2.03 \mathrm{M}$ & $1.81 \pm 0.18 \mathrm{M}$ \\
\hline NaOH & $2.21 \mathrm{M}$ & $2.00 \pm 0.20 \mathrm{M}$ \\
\hline $\mathrm{Na}_{2} \mathrm{SO}_{4}$ & $0.14 \mathrm{M}$ & $0.11 \pm 0.011 \mathrm{M}$ \\
\hline $\mathrm{NaAl}(\mathrm{OH})_{4}$ & $0.28 \mathrm{M}$ & $0.305 \pm 0.031 \mathrm{M}$ \\
\hline $\mathrm{NaNO}_{2}$ & $0.50 \mathrm{M}$ & $0.519 \pm 0.052 \mathrm{M}$ \\
\hline $\mathrm{NaCO}_{3}$ & $0.15 \mathrm{M}$ & $0.157 \pm 0.016$ \\
\hline Total Na & $5.6 \mathrm{M}$ & $5.83 \pm 0.58 \mathrm{M}$ \\
\hline Total Sr & $6.0 \mathrm{mg} / \mathrm{L}$ & $0.860 \pm 0.172 \mathrm{mg} / \mathrm{L}$ \\
\hline${ }^{85} \mathrm{Sr}$ & $\geq 10,000 \mathrm{dpm} / \mathrm{mL}$ & $10,300 \pm 130 \mathrm{dpm} / \mathrm{mL}$ \\
\hline Total Pu & $0.2 \mathrm{mg} / \mathrm{L}$ & $0.177 \pm 0.018 \mathrm{mg} / \mathrm{L}$ \\
\hline${ }^{237} \mathbf{N p}$ & $0.5 \mathrm{mg} / \mathrm{L}$ & $0.456 \pm 0.091 \mathrm{mg} / \mathrm{L}$ \\
\hline Total U & $10 \mathrm{mg} / \mathrm{L}$ & $9.84 \pm 1.97 \mathrm{mg} / \mathrm{L}$ \\
\hline${ }^{137} \mathrm{Cs}$ & $\geq 30,000 \mathrm{dpm} / \mathrm{mL}$ & $112,000 \pm 5600 \mathrm{dpm} / \mathrm{mL}$ \\
\hline
\end{tabular}

\subsection{Orbital Shaker Tests}

The majority of previous sorption testing for MST has utilized a controlled-temperature waterbath equipped with an orbital shaker operating at $200 \mathrm{rpm}$ to provide the mixing. The mixing energy supplied by the orbital shaker suspends a small fraction of the MST particles, while the bulk of the MST solids remain on and move along the bottom of the test bottle, briefly lifting up off the bottom when reaching the side wall of the bottle. A series of tests were performed in the waterbath-shaker using simulant SWS-5-2010 for comparison to the results from the SCIX mixing studies. The composition of the simulant used for these tests is given in Table 2-1.

These tests were performed by adding $200 \mathrm{~mL}$ of simulant SWS-5-2010 to each of three $250-\mathrm{mL}$ polyethylene bottles: "Control - No sorbent", "MST-Shaker", and "mMST-Shaker". A small piece of the Masterflex ${ }^{\circledR}$ tubing used for the SCIX tests was added to the "Control - No sorbent" bottle. This bottle was sampled at each sampling event to monitor for any changes in sorbate concentration due to precipitation or sorption by the polyethylene bottle or tubing. MST and mMST were added to the remaining two bottles at concentrations of $0.4 \mathrm{~g} / \mathrm{L}$ and $0.2 \mathrm{~g} / \mathrm{L}$, respectively. The MST used in these experiments was supplied by Optima, Lot \# 00-QAB-417. 
The mMST used in these experiments, batch LS-10, was prepared in the lab by treating a sample of the Optima 00-QAB-417 material with hydrogen peroxide following a previously published procedure. $^{7}$

After adding the sorbents, the bottles were placed in the waterbath shaker, maintained at an average temperature of $23.59 \pm 0.67^{\circ} \mathrm{C}$, and were continually shaken. Samples were removed at times of $6,12,24,48$, and 72 hours, and then weekly for a total of 6 weeks. At each sampling event, the bottle was removed from the waterbath and manually shaken for 30 seconds to ensure the solids were homogeneously suspended. A sample was then removed and filtered through a $0.1 \mu \mathrm{m}$ polyvinylidene fluoride (PVDF) syringe filter to remove the solids. An aliquot of the filtrate was acidified with an equal volume of $5 \mathrm{M}$ nitric acid and submitted for inductively coupled plasma - mass spectroscopy (ICP-MS), gamma scan, and plutonium thenoyltrifluoroacetone scintillation (PuTTA) analyses.

\section{4 $\underline{\text { SCIX Mixing Tests }}$}

Sorption tests were carried out using the simulated waste solution SWS-5-2010, having the composition shown in Table 2-1. Three liters of this simulant was placed in each of two open top polyethylene containers. The containers were prepared from 10-L carboys by cutting off the top to form an open vessel with a similar height to diameter ratio for the slurry as a 1.3 million-gallon waste tank. Glass lids containing two tubing inlets on opposite sides, a sampling port in the middle, and a temperature probe were fitted over the top of the containers. See Figure 1 for a photograph of the vessel. The tubing inlets were designed so that the intake end of the tubing was located near the top of the solution (to minimize uptake of solids) and the outlet was located near the bottom of the vessel. The experiments were performed at ambient laboratory temperature. The average temperatures for the MST and mMST tests were $29.2 \pm 1.4{ }^{\circ} \mathrm{C}$ and $27.3 \pm 2.7{ }^{\circ} \mathrm{C}$, respectively. The pump was initially operated before adding the sorbents to fill the tubing with solution. After priming, the pumping was stopped, and MST and mMST were added through the sampling ports of each vessel to reach concentrations of $0.4 \mathrm{~g} / \mathrm{L}$ and $0.2 \mathrm{~g} / \mathrm{L}$, respectively. The MST and mMST were added as $15 \mathrm{wt} \%$ slurries without $\mathrm{pH}$ adjustment (MST slurry is $\mathrm{pH} 10$ and mMST slurry is $\mathrm{pH} 4$ ). The same batches of MST and mMST used for the shaker tests were also used in these tests. The pumping was then resumed at a rate of 2.09 gallons/minute. Samples were removed after 6, 12, 24, 48, and 72 hours and then weekly for 4-5 weeks. Samples were removed through the sampling port using a large disposable pipette. Samples were filtered through a $0.1 \mu \mathrm{m}$ PVDF filter to remove any solids. An aliquot of the filtrate was acidified with an equal volume of $5 \mathrm{M}$ nitric acid and submitted for ICP-MS, gamma scan, and PuTTA analyses.

On day 6 of the experiment a leak was discovered in the mMST test. Based on the temperature data the leak occurred at the 109 hour time point, and was discovered and rectified at 147 hours. Approximately half of the solution had been lost. A sample was taken, the tubing was replaced, and the test was continued. On day 13 of the testing a leak was discovered in the MST experiment. Based on the temperature data the leak occurred at the 308 hour time point, and was discovered and rectified at 318 hours. Approximately half of the solution had been lost. A sample was taken, the tubing was replaced, and the test was continued. 


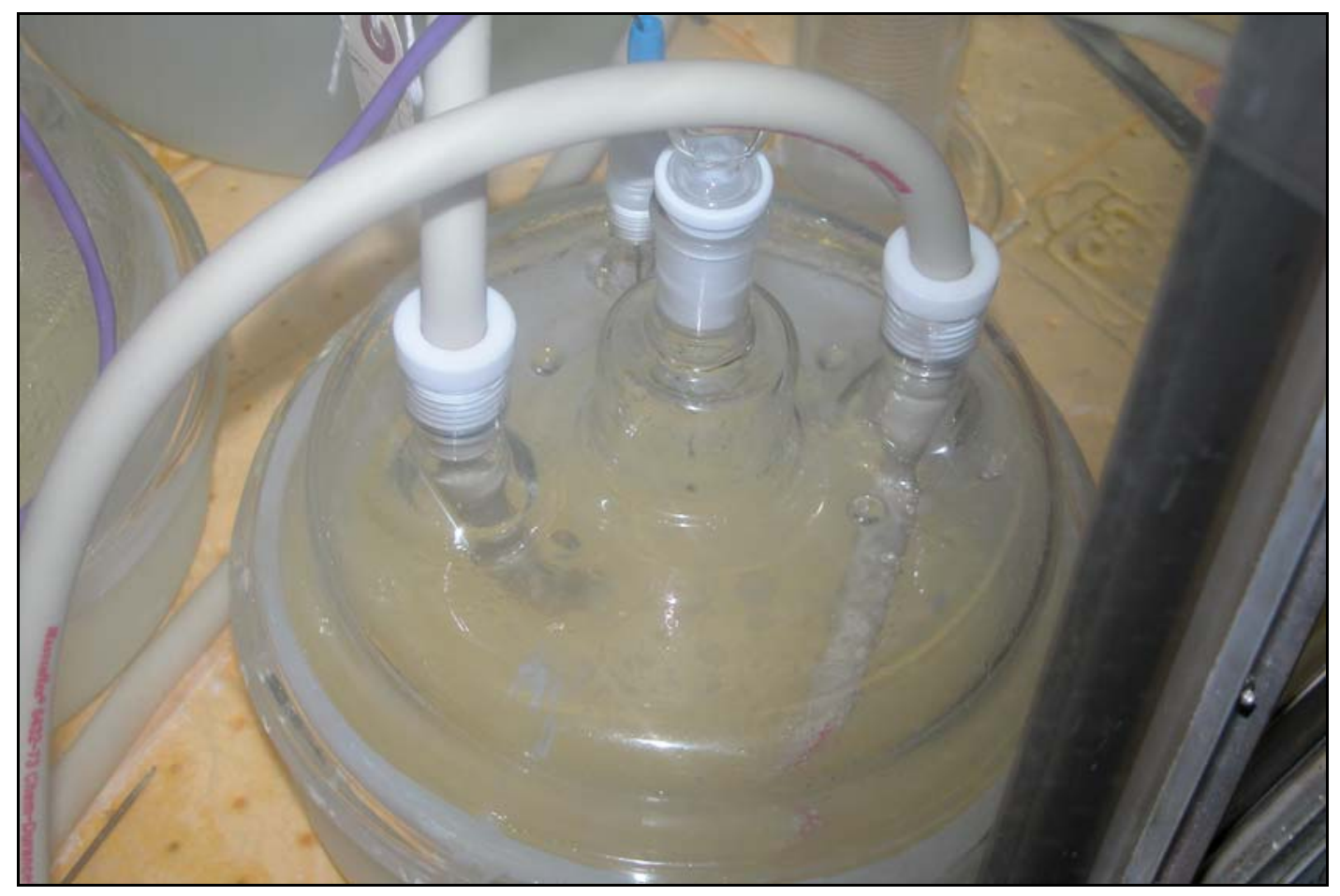

Figure 1. Photo of SCIX mixing test vessel.

\subsection{Results and Discussion}

Figures 2-5 show the Sr and actinide concentrations as a function of time for both the shaker tests and the SCIX mixing (pump) tests. The decontamination factors (DF) are summarized in Tables 3-1 through 3-4, and the plots of DF versus time are provided in the Appendix. Results from the control samples indicated no change in sorbate concentrations over the course of the experiment. When comparing the data from the first week of the test, similar removal kinetics were seen for both types of mixing (i.e., shaker versus recirculating pump). These results indicate that bulk solution transport is not the rate limiting step for $\mathrm{Sr}$ and actinide removal under the conditions tested. Sr removal was found to be rapid using both MST and mMST, reaching steady-state conditions after only six hours. For Pu removal in the shaker tests (see Figure 4), the mMST reached steady-state conditions within two weeks, and 99\% removal after only 72 hours. For MST, 6 weeks or more is necessary to reach steady-state conditions. Removal of $90 \%$ of the Pu is achieved after 1 week of contact with MST, and $95 \%$ is removed within 2 weeks of contact. In the shaker test with baseline MST, the Np concentration (see Figure 5) appeared to be continually decreasing through the six week test period, while with mMST it appeared steady-state conditions were reached after about 4 weeks. The MST also continued to sorb U over the six week test period in the shaker test, while mMST showed no affinity for $U$, as previously observed (see Figure 6).

After the leaks occurred, day 6 for the mMST test and day 13 for the MST test, the concentrations of some of the sorbates in these tests were found to increase. A minimal portion of this increasing concentration could be attributed to the small amount of evaporation expected over the duration of the experiment, since the containers do not have an air tight seal. However, the magnitude of the increase in ${ }^{85} \mathrm{Sr}$ and $\mathrm{Pu}$ concentrations is inconsistent with the increase in other sorbate concentrations, specifically $\mathrm{Cs}, \mathrm{Np}$, and $\mathrm{U}$, indicating evaporation is not solely responsible for the increasing concentrations of ${ }^{85} \mathrm{Sr}$ and $\mathrm{Pu}$. In both the baseline and modified MST tests, the Cs concentration was found to increase by a factor of approximately 1.5 from the 
time of the leak until the end of the experiment (see Figure 7). Since Cs is not adsorbed by MST or mMST this increase in concentration must be due to the concentrating of the solution, not by a desorption mechanism. The $\mathrm{U}$ concentrations were also observed to increase by a similar factor of 1.5 - 1.6. In the case of Np, no increase in concentration was observed in the baseline MST test, and an increase in concentration of about 1.7 was observed in the final data point for the mMST test. In contrast, the ${ }^{85} \mathrm{Sr}$ concentrations increased by factors of 2.4 and $>5.4$ for the MST and mMST tests, respectively. The Pu concentrations increased by factors of 5.1 and 5.2 for the MST and mMST tests, respectively. The large increases observed in the ${ }^{85} \mathrm{Sr}$ and $\mathrm{Pu}$ concentrations indicate potential desorption of these sorbates from the MST and mMST due to the change in solids to liquid phase ratio.

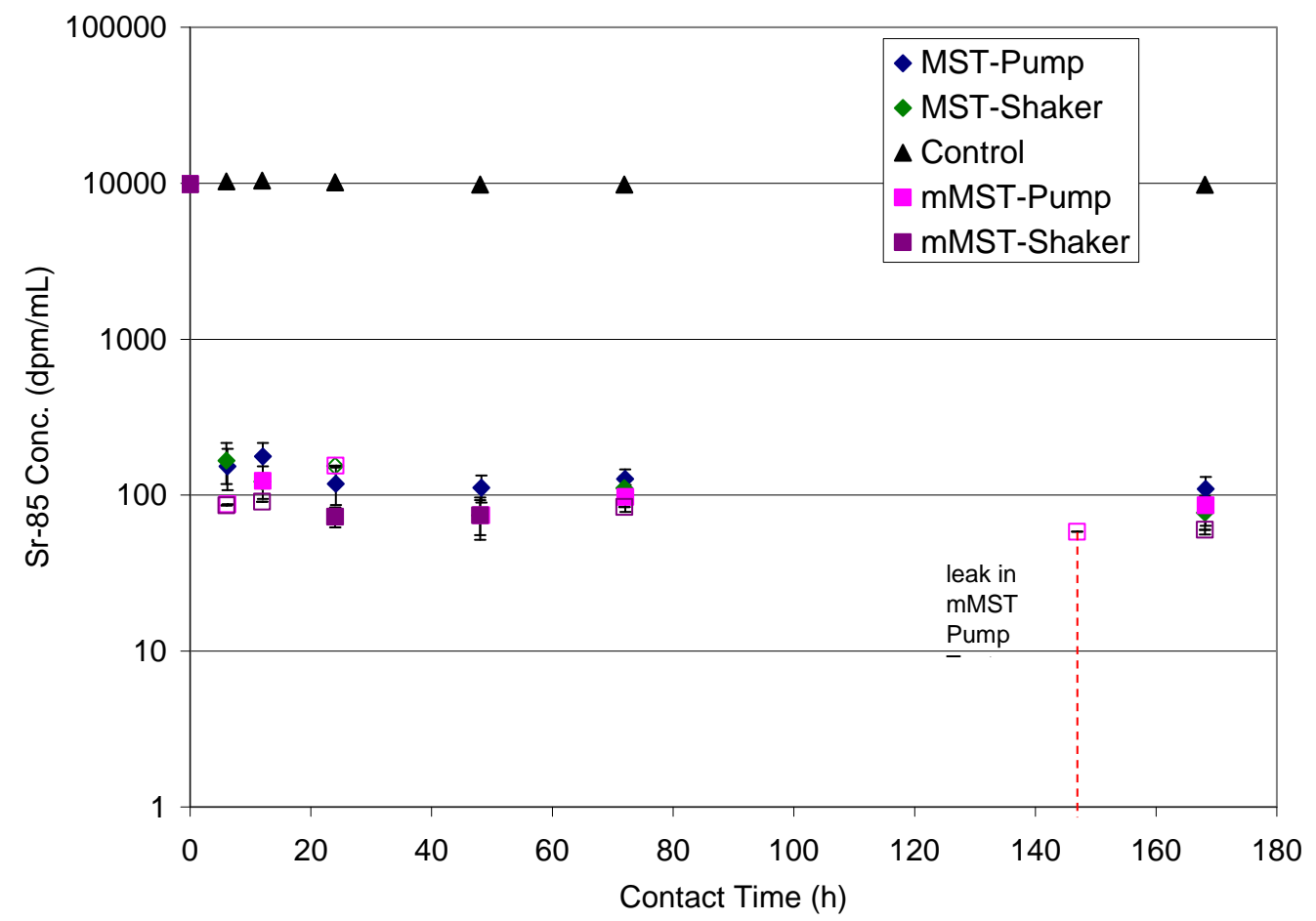

Figure 2. ${ }^{85} \mathrm{Sr}$ activity versus contact time for the first week of testing. Open data points identify maximum concentrations (i.e., measured concentrations are at detection limits). 
SRNL-STI-2011-00215

Revision 0

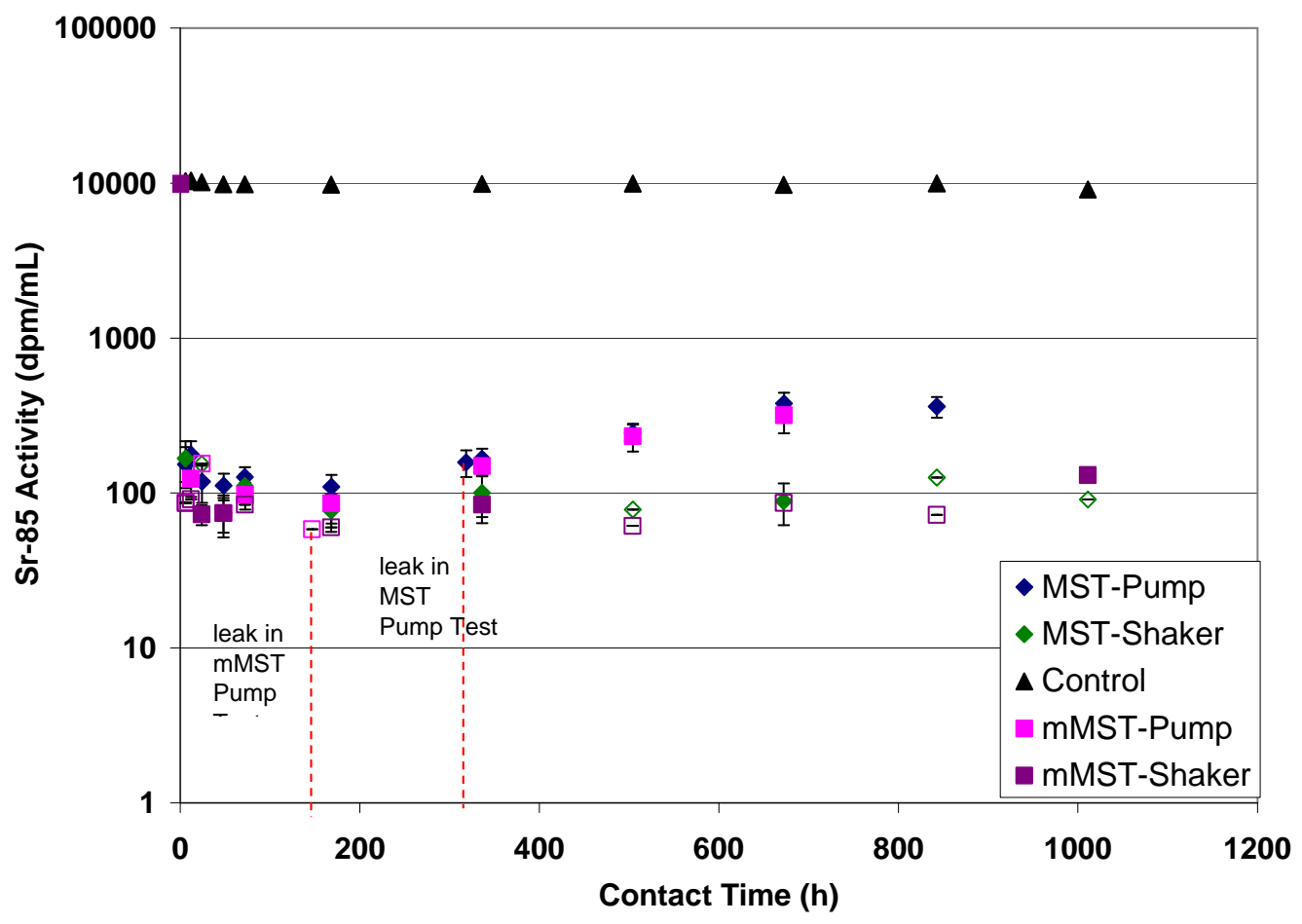

Figure $3 .{ }^{85} \mathrm{Sr}$ activity versus contact time. Open data points identify maximum concentrations (i.e., measured concentrations are at detection limits).

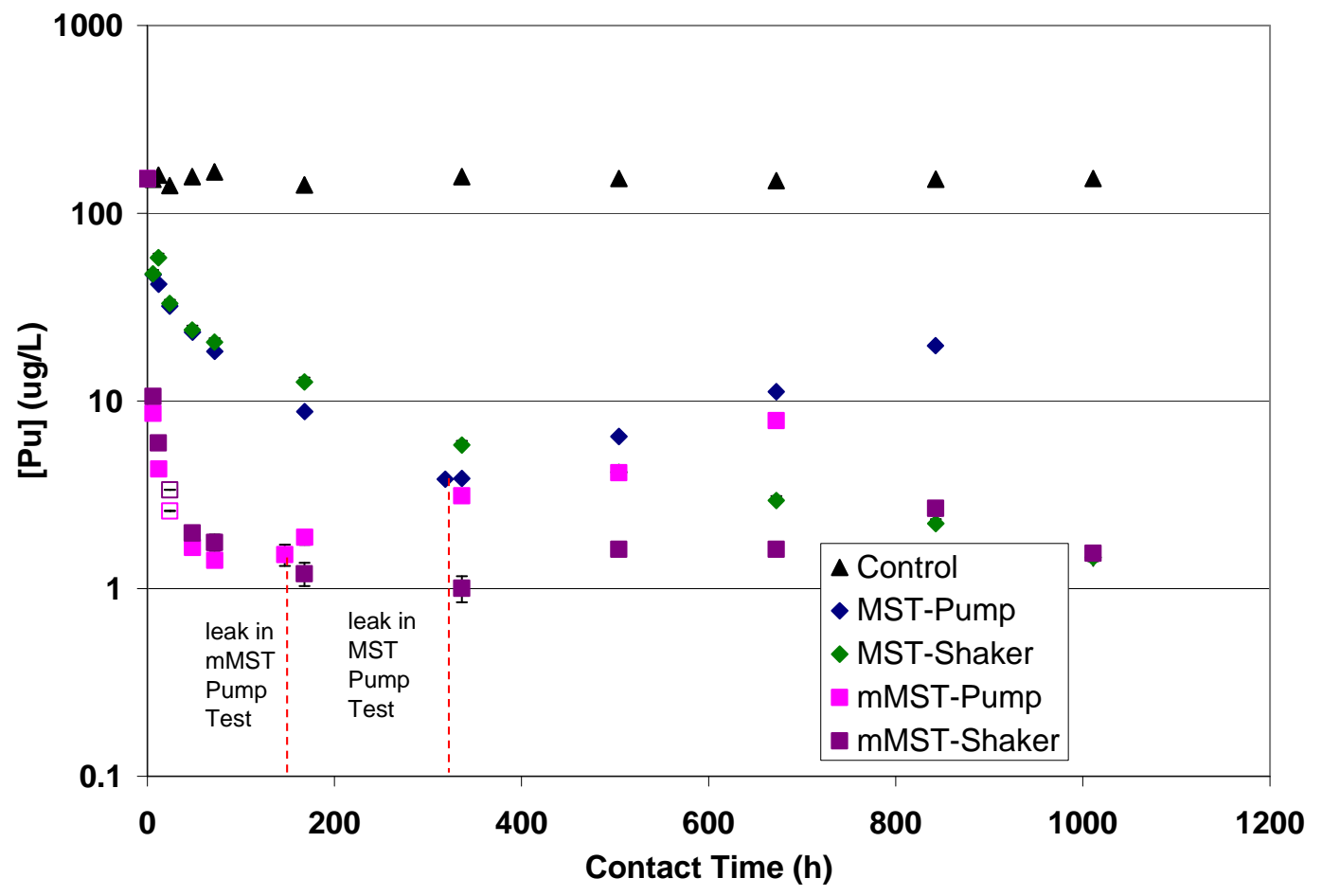

Figure 4. Total Pu concentration (from PuTTA data) versus contact time. Open data points identify maximum concentrations (i.e., measured concentrations are at detection limits). 


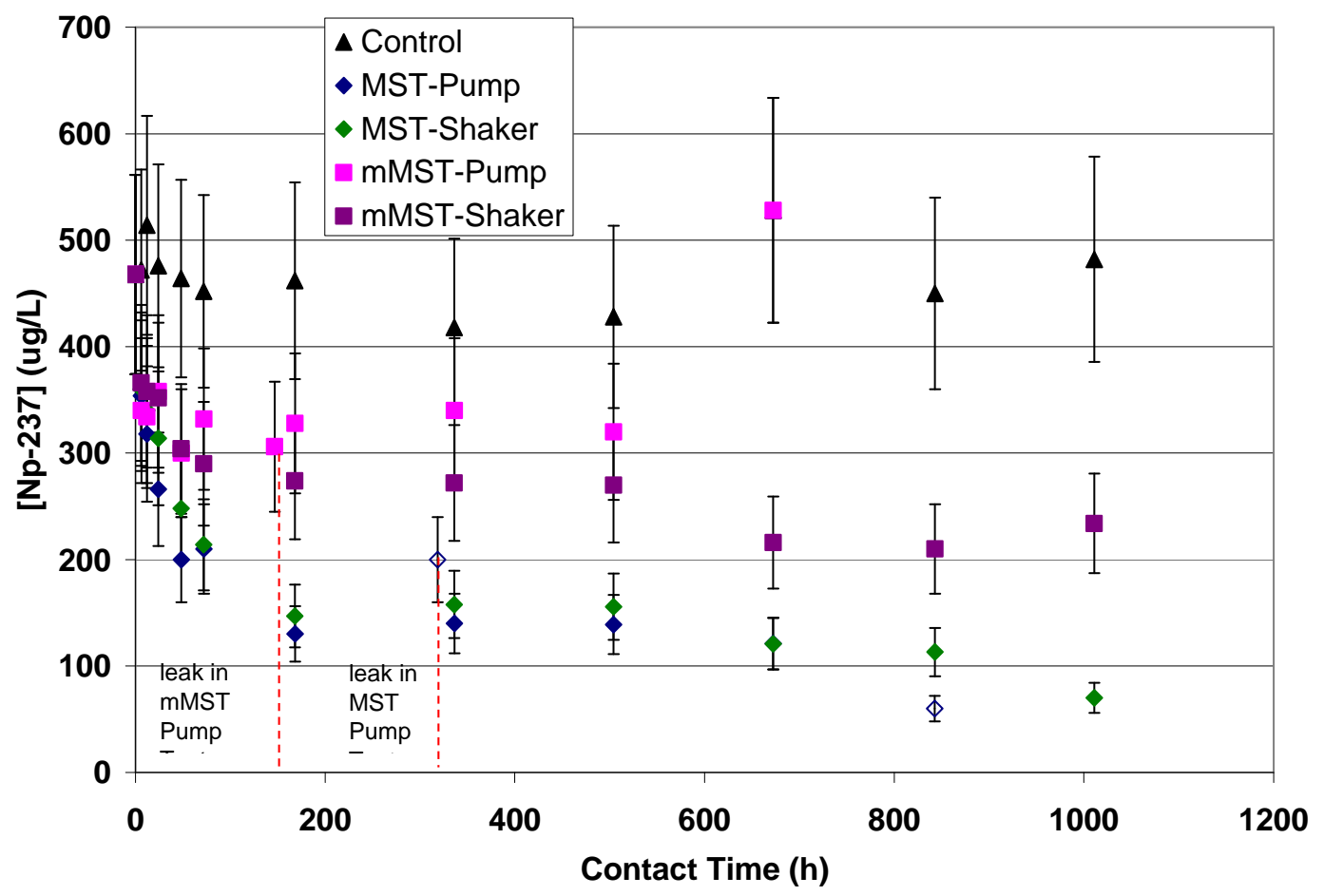

Figure 5. ${ }^{237} \mathrm{~Np}$ concentration (from ICP-MS data) versus contact time. Open data points identify maximum concentrations (i.e., measured concentrations are at detection limits).

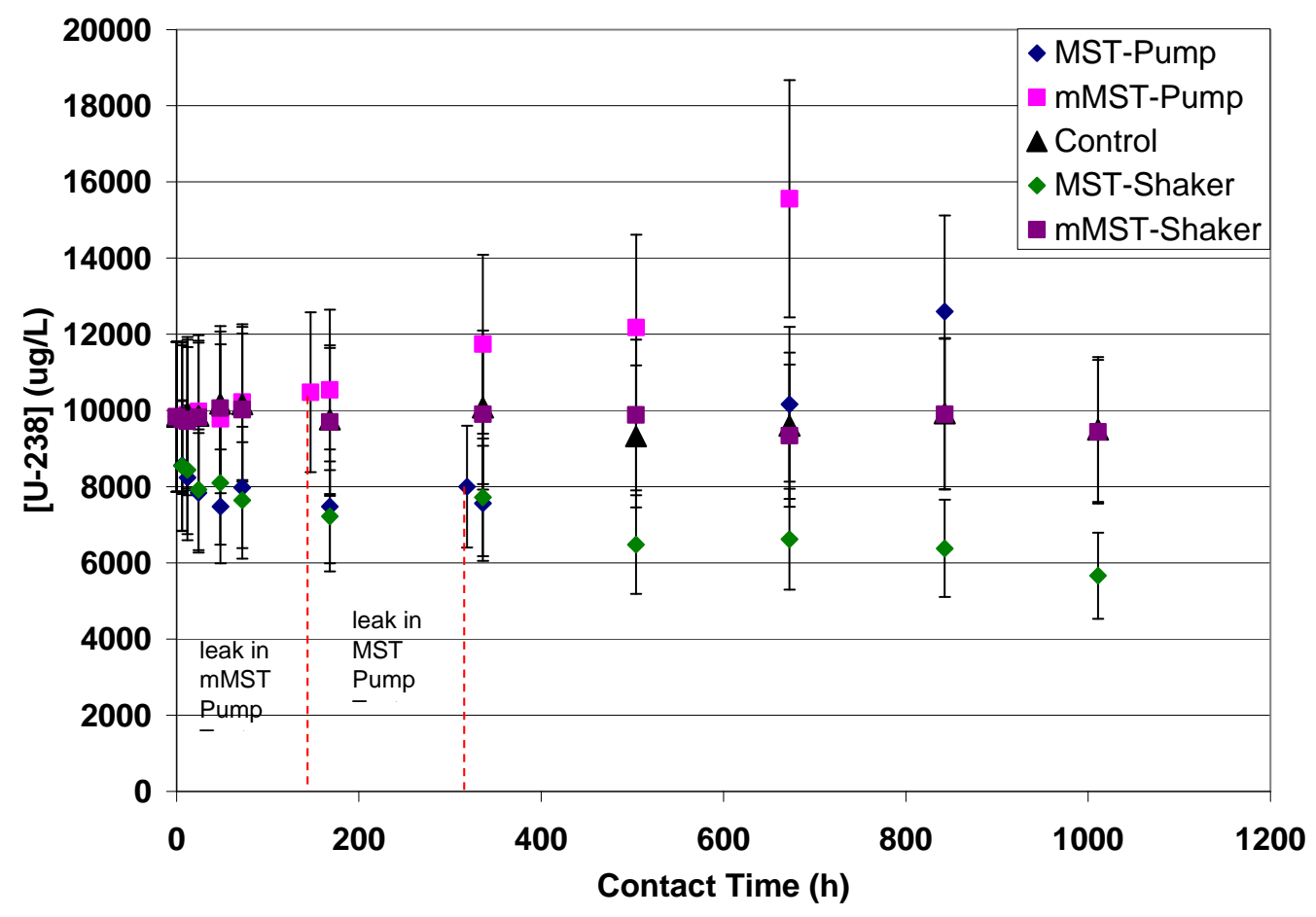

Figure 6. ${ }^{238} \mathrm{U}$ concentration (from ICP-MS data) versus contact time. 
SRNL-STI-2011-00215

Revision 0

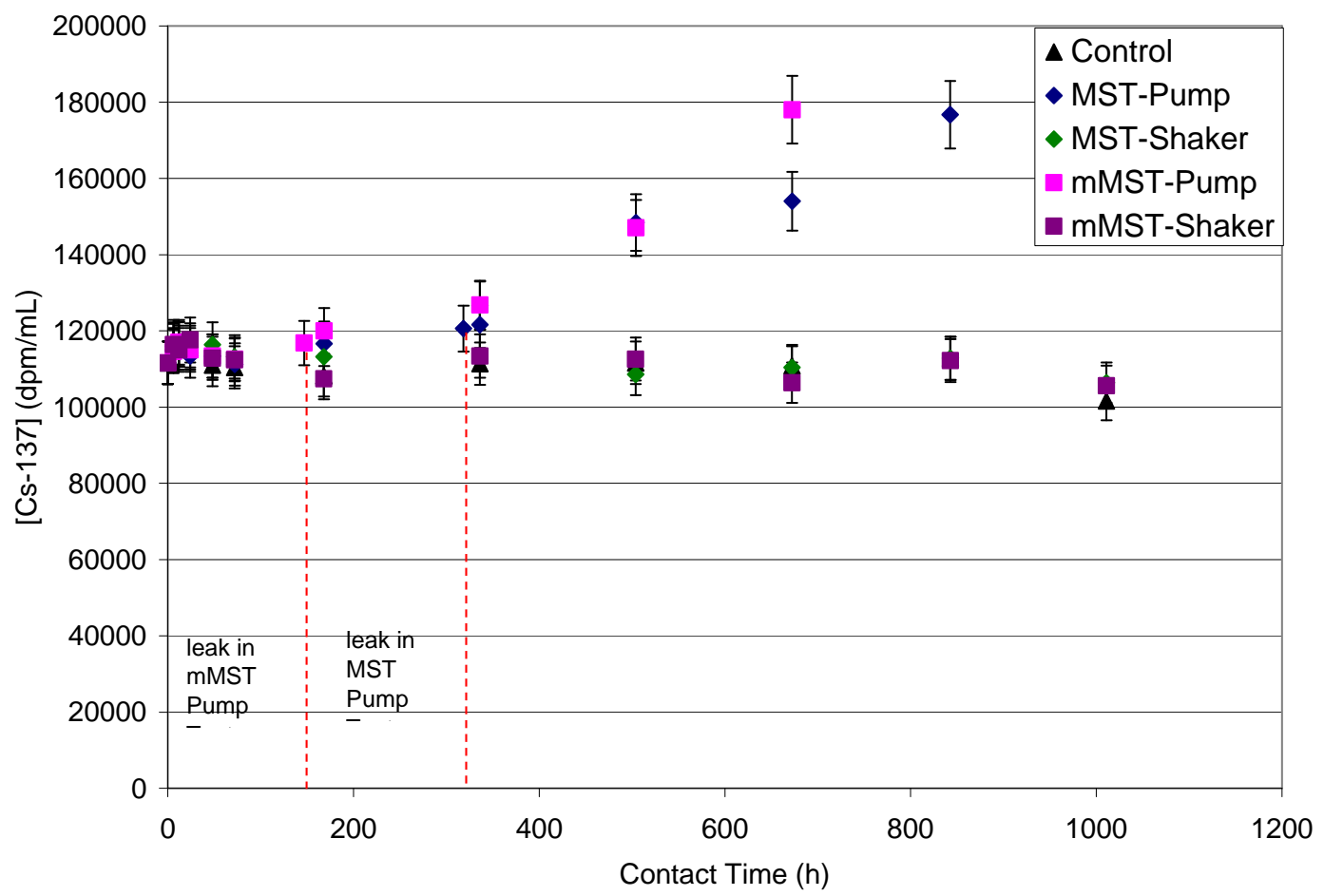

Figure 7. ${ }^{137}$ Cs activity versus contact time.

Table 3-1. Summary of ${ }^{85} \mathrm{Sr}$ Decontamination Factors (DF). The uncertainty (Unc.) column represents one sigma uncertainty. The shaded boxes indicate data points taken after the leak was discovered.

\begin{tabular}{|c|c|c|c|c|c|c|c|c|}
\hline \multicolumn{9}{|c|}{${ }^{85} \mathrm{Sr}$ DF } \\
\hline \multirow{3}{*}{$\begin{array}{c}\text { Contact } \\
\text { Time }\end{array}$} & \multicolumn{4}{|c|}{ MST } & \multicolumn{4}{|c|}{ mMST } \\
\hline & \multicolumn{2}{|c|}{ Shaker } & \multicolumn{2}{|c|}{ Pump } & \multicolumn{2}{|c|}{ Shaker } & \multicolumn{2}{|c|}{ Pump } \\
\hline & DF & Unc. & DF & Unc. & DF & Unc. & DF & Unc. \\
\hline $6 \mathrm{~h}$ & 61.7 & 18.4 & 67.2 & 20.2 & $>120$ & $\mathrm{n} / \mathrm{a}$ & $>118$ & $\mathrm{n} / \mathrm{a}$ \\
\hline $12 \mathrm{~h}$ & $>85.3$ & $\mathrm{n} / \mathrm{a}$ & 58.9 & 13.5 & $>114$ & $\mathrm{n} / \mathrm{a}$ & 84.2 & 20.2 \\
\hline $24 \mathrm{~h}$ & $>66.0$ & $\mathrm{n} / \mathrm{a}$ & 85.9 & 23.5 & 140 & 21.5 & $>65.7$ & $\mathrm{n} / \mathrm{a}$ \\
\hline $48 \mathrm{~h}$ & 132 & 33.9 & 87.9 & 17.9 & 132 & 40.5 & $>132$ & $\mathrm{n} / \mathrm{a}$ \\
\hline $72 \mathrm{~h}$ & 88.6 & 17.8 & 77.4 & 12.5 & $>117$ & $\mathrm{n} / \mathrm{a}$ & 101 & 20.5 \\
\hline $6 \mathrm{~d}$ & $\mathrm{n} / \mathrm{a}$ & $\mathrm{n} / \mathrm{a}$ & $\mathrm{n} / \mathrm{a}$ & $\mathrm{n} / \mathrm{a}$ & $\mathrm{n} / \mathrm{a}$ & $\mathrm{n} / \mathrm{a}$ & $>168$ & $\mathrm{n} / \mathrm{a}$ \\
\hline $1 \mathrm{wk}$ & 127 & 35.2 & 89.3 & 18.0 & $>163$ & $\mathrm{n} / \mathrm{a}$ & 114 & 30.3 \\
\hline $13 \mathrm{~d}$ & $\mathrm{n} / \mathrm{a}$ & $\mathrm{n} / \mathrm{a}$ & 62.8 & 12.7 & $\mathrm{n} / \mathrm{a}$ & $\mathrm{n} / \mathrm{a}$ & $\mathrm{n} / \mathrm{a}$ & $\mathrm{n} / \mathrm{a}$ \\
\hline $2 \mathrm{wk}$ & 98.8 & 30.0 & 59.4 & 10.0 & 118 & 28.8 & 66 & 10.0 \\
\hline $3 \mathrm{wk}$ & $>127$ & $\mathrm{n} / \mathrm{a}$ & 40.5 & 5.60 & $>161$ & $\mathrm{n} / \mathrm{a}$ & 42.7 & 8.92 \\
\hline $4 \mathrm{wk}$ & 110 & 33.4 & 25.8 & 4.67 & $>113$ & $\mathrm{n} / \mathrm{a}$ & 30.7 & 7.41 \\
\hline $5 \mathrm{wk}$ & $>79.0$ & $\mathrm{n} / \mathrm{a}$ & 27.5 & 4.46 & $>138$ & $\mathrm{n} / \mathrm{a}$ & $\mathrm{n} / \mathrm{a}$ & $\mathrm{n} / \mathrm{a}$ \\
\hline $6 \mathrm{wk}$ & $>100$ & $\mathrm{n} / \mathrm{a}$ & $\mathrm{n} / \mathrm{a}$ & $\mathrm{n} / \mathrm{a}$ & $>69.6$ & $\mathrm{n} / \mathrm{a}$ & $\mathrm{n} / \mathrm{a}$ & $\mathrm{n} / \mathrm{a}$ \\
\hline
\end{tabular}


Table 3-2. Summary of Pu Decontamination Factors (DF). The uncertainty (Unc.) column represents one sigma uncertainty. The shaded boxes indicate data points taken after the leak was discovered.

\begin{tabular}{|c|c|c|c|c|c|c|c|c|}
\hline \multicolumn{9}{|c|}{ Pu DF } \\
\hline \multirow{3}{*}{$\begin{array}{c}\text { Contact } \\
\text { Time }\end{array}$} & \multicolumn{4}{|c|}{ MST } & \multicolumn{4}{|c|}{ mMST } \\
\hline & \multicolumn{2}{|c|}{ Shaker } & \multicolumn{2}{|c|}{ Pump } & \multicolumn{2}{|c|}{ Shaker } & \multicolumn{2}{|c|}{ Pump } \\
\hline & DF & Unc. & DF & Unc. & DF & Unc. & DF & Unc. \\
\hline $6 \mathrm{~h}$ & 3.19 & 0.211 & 3.23 & 0.217 & 14.4 & 0.996 & 17.7 & 1.39 \\
\hline $12 \mathrm{~h}$ & 2.75 & 0.195 & 3.81 & 0.265 & 26.7 & 1.96 & 36.8 & 3.03 \\
\hline $24 \mathrm{~h}$ & 4.25 & 0.279 & 4.38 & 0.340 & $>41.8$ & $\mathrm{n} / \mathrm{a}$ & $>54.2$ & $\mathrm{n} / \mathrm{a}$ \\
\hline $48 \mathrm{~h}$ & 6.58 & 0.473 & 6.76 & 0.456 & 79.3 & 7.65 & 94.6 & 7.98 \\
\hline $72 \mathrm{~h}$ & 8.08 & 0.570 & 9.03 & 0.635 & 94.2 & 10.5 & 117 & 10.5 \\
\hline $6 \mathrm{~d}$ & $\mathrm{n} / \mathrm{a}$ & $\mathrm{n} / \mathrm{a}$ & $\mathrm{n} / \mathrm{a}$ & $\mathrm{n} / \mathrm{a}$ & $\mathrm{n} / \mathrm{a}$ & $\mathrm{n} / \mathrm{a}$ & 93.3 & 14.2 \\
\hline $1 \mathrm{wk}$ & 11.2 & 1.08 & 16.2 & 1.54 & 118 & 19.1 & 75.5 & 8.56 \\
\hline $13 \mathrm{~d}$ & $\mathrm{n} / \mathrm{a}$ & $\mathrm{n} / \mathrm{a}$ & 41.0 & 2.74 & $\mathrm{n} / \mathrm{a}$ & $\mathrm{n} / \mathrm{a}$ & $\mathrm{n} / \mathrm{a}$ & $\mathrm{n} / \mathrm{a}$ \\
\hline $2 \mathrm{wk}$ & 27.0 & 1.93 & 40.6 & 3.45 & 156 & 25.8 & 50.2 & 4.04 \\
\hline $3 \mathrm{wk}$ & 36.8 & 2.85 & 23.7 & 1.73 & 94.5 & 7.26 & 36.9 & 2.75 \\
\hline $4 \mathrm{wk}$ & 50.7 & 3.73 & 13.3 & 0.929 & 92.1 & 6.95 & 19.0 & 1.32 \\
\hline $5 \mathrm{wk}$ & 68.4 & 5.15 & 7.70 & 0.537 & 56.7 & 5.76 & $\mathrm{n} / \mathrm{a}$ & $\mathrm{n} / \mathrm{a}$ \\
\hline $6 \mathrm{wk}$ & 104 & 12.6 & $\mathrm{n} / \mathrm{a}$ & $\mathrm{n} / \mathrm{a}$ & 99.2 & 11.4 & $\mathrm{n} / \mathrm{a}$ & $\mathrm{n} / \mathrm{a}$ \\
\hline
\end{tabular}

Table 3-3. Summary of Np Decontamination Factors (DF). The uncertainty (Unc.) column represents one sigma uncertainty. The shaded boxes indicate data points taken after the leak was discovered.

\begin{tabular}{|c|c|c|c|c|c|c|c|c|}
\hline \multicolumn{9}{|c|}{ Np DF } \\
\hline \multirow{3}{*}{$\begin{array}{c}\text { Contact } \\
\text { Time }\end{array}$} & \multicolumn{4}{|c|}{ MST } & \multicolumn{4}{|c|}{ mMST } \\
\hline & \multicolumn{2}{|c|}{ Shaker } & \multicolumn{2}{|c|}{ Pump } & \multicolumn{2}{|c|}{ Shaker } & \multicolumn{2}{|c|}{ Pump } \\
\hline & DF & Unc. & DF & Unc. & DF & Unc. & DF & Unc. \\
\hline $6 \mathrm{~h}$ & 1.31 & 0.371 & 1.33 & 0.377 & 1.29 & 0.365 & 1.39 & 0.393 \\
\hline $12 \mathrm{~h}$ & 1.51 & 0.428 & 1.62 & 0.457 & 1.44 & 0.406 & 1.54 & 0.435 \\
\hline $24 \mathrm{~h}$ & 1.52 & 0.429 & 1.79 & 0.506 & 1.35 & 0.382 & 1.33 & 0.376 \\
\hline $48 \mathrm{~h}$ & 1.87 & 0.529 & 2.32 & 0.656 & 1.53 & 0.432 & 1.55 & 0.437 \\
\hline $72 \mathrm{~h}$ & 2.11 & 0.597 & 2.15 & 0.610 & 1.56 & 0.441 & 1.36 & 0.385 \\
\hline $6 \mathrm{~d}$ & $\mathrm{n} / \mathrm{a}$ & $\mathrm{n} / \mathrm{a}$ & $\mathrm{n} / \mathrm{a}$ & $\mathrm{n} / \mathrm{a}$ & $\mathrm{n} / \mathrm{a}$ & $\mathrm{n} / \mathrm{a}$ & 1.51 & 0.427 \\
\hline $1 \mathrm{wk}$ & 3.14 & 0.889 & 3.55 & 1.00 & 1.69 & 0.477 & 1.41 & 0.398 \\
\hline $13 \mathrm{~d}$ & $\mathrm{n} / \mathrm{a}$ & $\mathrm{n} / \mathrm{a}$ & $>2.09$ & $\mathrm{n} / \mathrm{a}$ & $\mathrm{n} / \mathrm{a}$ & $\mathrm{n} / \mathrm{a}$ & $\mathrm{n} / \mathrm{a}$ & $\mathrm{n} / \mathrm{a}$ \\
\hline $2 \mathrm{wk}$ & 2.65 & 0.749 & 2.99 & 0.844 & 1.54 & 0.435 & 1.23 & 0.348 \\
\hline $3 \mathrm{wk}$ & 2.75 & 0.777 & 3.08 & 0.871 & 1.59 & 0.488 & 1.34 & 0.378 \\
\hline $4 \mathrm{wk}$ & 4.37 & 1.24 & 4.36 & 1.34 & 2.44 & 0.691 & 1.00 & 0.283 \\
\hline $5 \mathrm{wk}$ & 3.98 & 1.12 & $>7.50$ & $\mathrm{n} / \mathrm{a}$ & 2.14 & 0.606 & $\mathrm{n} / \mathrm{a}$ & $\mathrm{n} / \mathrm{a}$ \\
\hline $6 \mathrm{wk}$ & 6.87 & 1.94 & $\mathrm{n} / \mathrm{a}$ & $\mathrm{n} / \mathrm{a}$ & 2.06 & 0.583 & $\mathrm{n} / \mathrm{a}$ & $\mathrm{n} / \mathrm{a}$ \\
\hline
\end{tabular}


Table 3-4. Summary of ${ }^{238}$ U Decontamination Factors (DF). The uncertainty (Unc.) column represents one sigma uncertainty. The shaded boxes indicate data points taken after the leak was discovered.

\begin{tabular}{|c|c|c|c|c|c|c|c|c||}
\hline \hline \multirow{2}{*}{$\begin{array}{c}\text { Contact } \\
\text { Time }\end{array}$} & \multicolumn{9}{|c|}{ MST } & \multicolumn{3}{c|}{ U DF } & \multicolumn{3}{c||}{ mMST } \\
\cline { 2 - 9 } & \multicolumn{2}{|c|}{ Shaker } & \multicolumn{2}{c|}{ Pump } & \multicolumn{2}{c|}{ Shaker } & \multicolumn{2}{c|}{ Pump } \\
\cline { 2 - 9 } & DF & Unc. & DF & Unc. & DF & Unc. & DF & Unc. \\
\hline $6 \mathrm{~h}$ & 1.15 & 0.326 & 1.15 & 0.325 & 1.01 & 0.285 & 1.00 & 0.283 \\
\hline $12 \mathrm{~h}$ & 1.18 & 0.333 & 1.21 & 0.341 & 1.02 & 0.289 & 1.01 & 0.285 \\
\hline $24 \mathrm{~h}$ & 1.24 & 0.352 & 1.26 & 0.356 & 1.00 & 0.284 & 0.988 & 0.279 \\
\hline $48 \mathrm{~h}$ & 1.26 & 0.355 & 1.36 & 0.385 & 1.01 & 0.286 & 1.04 & 0.294 \\
\hline $72 \mathrm{~h}$ & 1.33 & 0.376 & 1.27 & 0.360 & 1.01 & 0.287 & 0.994 & 0.281 \\
\hline $6 \mathrm{~d}$ & $\mathrm{n} / \mathrm{a}$ & $\mathrm{n} / \mathrm{a}$ & $\mathrm{n} / \mathrm{a}$ & $\mathrm{n} / \mathrm{a}$ & $\mathrm{n} / \mathrm{a}$ & $\mathrm{n} / \mathrm{a}$ & 0.931 & 0.263 \\
\hline $1 \mathrm{wk}$ & 1.35 & 0.382 & 1.30 & 0.369 & 1.01 & 0.285 & 0.926 & 0.262 \\
\hline $13 \mathrm{~d}$ & $\mathrm{n} / \mathrm{a}$ & $\mathrm{n} / \mathrm{a}$ & 1.26 & 0.356 & $\mathrm{n} / \mathrm{a}$ & $\mathrm{n} / \mathrm{a}$ & $\mathrm{n} / \mathrm{a}$ & $\mathrm{n} / \mathrm{a}$ \\
\hline $2 \mathrm{wk}$ & 1.31 & 0.369 & 1.33 & 0.377 & 1.02 & 0.288 & 0.859 & 0.243 \\
\hline $3 \mathrm{wk}$ & 1.44 & 0.407 & $\mathrm{n} / \mathrm{a}$ & $\mathrm{n} / \mathrm{a}$ & 0.943 & 0.267 & 0.765 & 0.216 \\
\hline $4 \mathrm{wk}$ & 1.45 & 0.410 & 0.945 & 0.267 & 1.03 & 0.291 & 0.617 & 0.175 \\
\hline $5 \mathrm{wk}$ & 1.57 & 0.440 & 0.787 & 0.223 & 1.00 & 0.283 & $\mathrm{n} / \mathrm{a}$ & $\mathrm{n} / \mathrm{a}$ \\
\hline $6 \mathrm{wk}$ & 1.68 & 0.475 & $\mathrm{n} / \mathrm{a}$ & $\mathrm{n} / \mathrm{a}$ & 1.01 & 0.285 & $\mathrm{n} / \mathrm{a}$ & $\mathrm{n} / \mathrm{a}$ \\
\hline
\end{tabular}

\subsection{Conclusions}

This testing served to determine if the mixing conditions planned for the SCIX Program would provide sufficient mixing for removal of strontium and actinides by MST. Testing showed that both types of mixing tested here, an orbital shaker and simulated SCIX pump mixing, resulted in similar removal kinetics indicating that bulk solution transport is not the rate limiting step. This result is consistent with previous lab-scale results. ${ }^{1}$ Results also showed that $\mathrm{Sr}$ removal by both MST and mMST is much more rapid than actinide removal. The ${ }^{85} \mathrm{Sr}$ concentration had reached steady-state conditions by the first sampling event at 6 hours. In contrast, $\mathrm{Pu}, \mathrm{Np}$, and $\mathrm{U}$ removal by MST continued through the entire test period, indicating six weeks or more is necessary to reach steady-state conditions for these sorbates. The actual contact time needed in the SCIX Program will depend on the starting sorbate concentrations and the requirements for the decontaminated solutions.

The leaks that occurred in the 3-L tests suggested that a changing solids to liquid phase ratio may result in desorption of the sorbates from the MST. It is believed that when the leak occurred approximately half of the liquid volume was lost. This resulted in an increase of the MST concentration from $0.4 \mathrm{~g} / \mathrm{L}$ to likely near $0.8 \mathrm{~g} / \mathrm{L}$. Results from calculations using the MST model indicated that this type of change in phase ratio could result in desorption of the sorbates from the MST back into solution. During SCIX processing, as decontaminated salt solution is pumped from the tank leaving behind an MST heel, a similar change in phase ratio will occur. Therefore, SRNL recommended additional desorption testing to confirm and further study the potential for desorption of sorbates from MST under changing phase ratio conditions. This testing is currently in progress and results will be documented in a separate report. 


\section{References}

1. D. T. Hobbs, "Review of Experimental Studies Investigating the Rate of Strontium and Actinide Adsorption by Monosodium Titanate", SRNL-STI-2010-00438, Rev. 0, October 2010.

2. T. H. Huff, "SRNL Testing to Support Modular Salt Processing Project - Resin Loading Studies", HLE-TTR-2010-001, Rev. 0, March 2010.

3. K. M. L. Taylor-Pashow, M. R. Poirier, Z. Qureshi, F. F. Fondeur, T. B. Peters, D. T. Hobbs, and S. D. Fink, "Task Technical and Quality Assurance Plan for Testing to Support Modular Salt Processing Project - Monosodium Titanate Studies", SRNL-RP2010-00686, Rev. 1, September 2010.

4. Peterson, R. A. "Preparation of Simulated Waste Solutions for Solvent Extraction Testing" WSRC-RP-2000-00361, Rev. 0, May 1, 2000.

5. Barnes, M. J.; Edwards, T. B.; Hobbs, D. T.; Marshall, K. M. "Strontium and Actinide Removal Testing with Monosodium Titanate and Other Sorbents" WSRC-TR-200100436, Rev. 0, October 29, 2001.

6. Stallings, M. E.; Barnes, M. J.; Peters, T. B.; Diprete, D. P.; Fondeur, F. F.; Hobbs, D. T.; Fink, S. D. "Characterization of Supernate Samples from High Level Waste Tanks 13H, 30H, 37H, 39H, 45F, 46F, and 49H” WSRC-TR-2004-00386, Rev. 2, June 15, 2005.

7. M. Nyman and D. T. Hobbs, "A Family of Peroxo-titanate Materials Tailored for Optimal Strontium and Actinide Sorption." Chem. Mater. 2006, 18, 6425. 
SRNL-STI-2011-00215

Revision 0

Appendix 


\section{Calculations for Determining Required Pump Speed}

\section{Equivalent Power for Bench-Scale MST Test and Full-Scale MST Strike}

\section{Scaling Bench-Scale Test to Full-Scale Tank}

At time of calculations it was assumed Tank $41 \mathrm{H}$ would contain 2 SMPs

$\mathrm{Dj}=4.4$ in $=0.367 \mathrm{ft}$

$\mathrm{Vj}=79 \mathrm{ft} / \mathrm{s}$

$$
\begin{aligned}
\mathrm{P}=(\pi / 8) \rho \mathrm{Dj}^{2} \mathrm{Vj}^{3} & =8.64 \times 10^{11} \mathrm{~g} \mathrm{~cm}^{2} / \mathrm{sec}^{3} \\
& =8.64 \times 10^{4} \text { Watts } \\
& =116 \mathrm{HP}
\end{aligned}
$$

Volume $=1,000,000$ gallons

$\mathrm{P} / \mathrm{V}=1.16 \times 10^{-4} \mathrm{HP} / \mathrm{gal}$

For 2 pumps (4 nozzles), $\mathrm{P} / \mathrm{V}=4.64 \times 10^{-4} \mathrm{HP} / \mathrm{gal}$

Lab-Scale will contain 1 pump and 1 nozzle

$\mathrm{Dj}=0.375$ in

Volume $=3$ Liters $=0.79$ gallons

For equal mass transfer, scale by constant power per unit volume

$\mathrm{P} / \mathrm{V}=4.64 \times 10^{-4} \mathrm{HP} / \mathrm{gal}$

$\mathrm{P}=4.64 \times 10^{-4} \mathrm{HP} / \mathrm{gal}(0.79 \mathrm{gal})=3.67 \times 10^{-4} \mathrm{HP}$

$$
\begin{aligned}
& =2.74 \times 10^{-1} \mathrm{Watts} \\
& =2.74 \times 10^{6} \mathrm{~g} \mathrm{~cm}^{2} / \mathrm{sec}^{3}
\end{aligned}
$$

$\mathrm{Dj}=0.375$ in $=0.0313 \mathrm{ft}$

$\mathrm{Vj}=6.08 \mathrm{ft} / \mathrm{s}$

$\mathrm{Q}=0.0047 \mathrm{ft}^{3} / \mathrm{s}=2.09 \mathrm{gpm} /$ nozzle $=2.09 \mathrm{gpm}$

$$
\begin{aligned}
& \mathrm{P}=(\pi / 8) \rho \mathrm{Dj}^{2} \mathrm{Vj}^{3}=2.85 \times 10^{6} \mathrm{~g} \mathrm{~cm}^{2} / \mathrm{sec}^{3} \\
& =2.85 \times 10^{-1} \mathrm{~W} \\
& =3.82 \times 10^{-4} \mathrm{HP}
\end{aligned}
$$

Reducing the flow rate to $2.06 \mathrm{gpm}$

$\mathrm{Vj}=6.00 \mathrm{ft} / \mathrm{s}$

$$
\begin{aligned}
& \mathrm{P}=(\pi / 8) \rho D j^{2} \mathrm{Vj}^{3}=2.74 \times 10^{6} \mathrm{~g} \mathrm{~cm}^{2} / \mathrm{sec}^{3} \\
& =2.74 \times 10^{-1} \mathrm{~W} \\
& =3.67 \times 10^{-4} \mathrm{HP}
\end{aligned}
$$


SRNL-STI-2011-00215

Revision 0

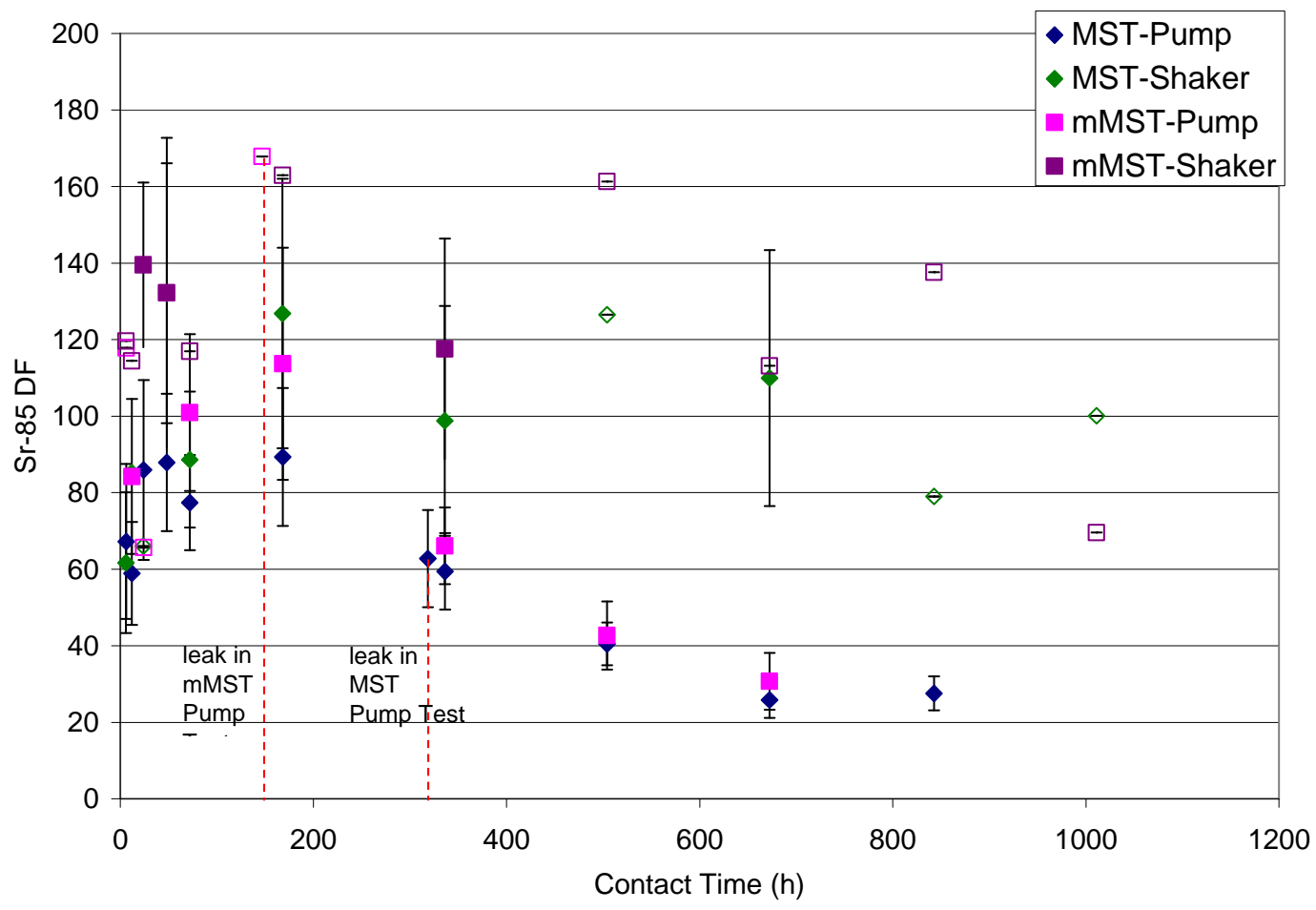

Figure A-1. ${ }^{85} \mathrm{Sr}$ DF versus contact time. Open data points indicate minimum DF values (i.e., measured concentrations are at detection limits).

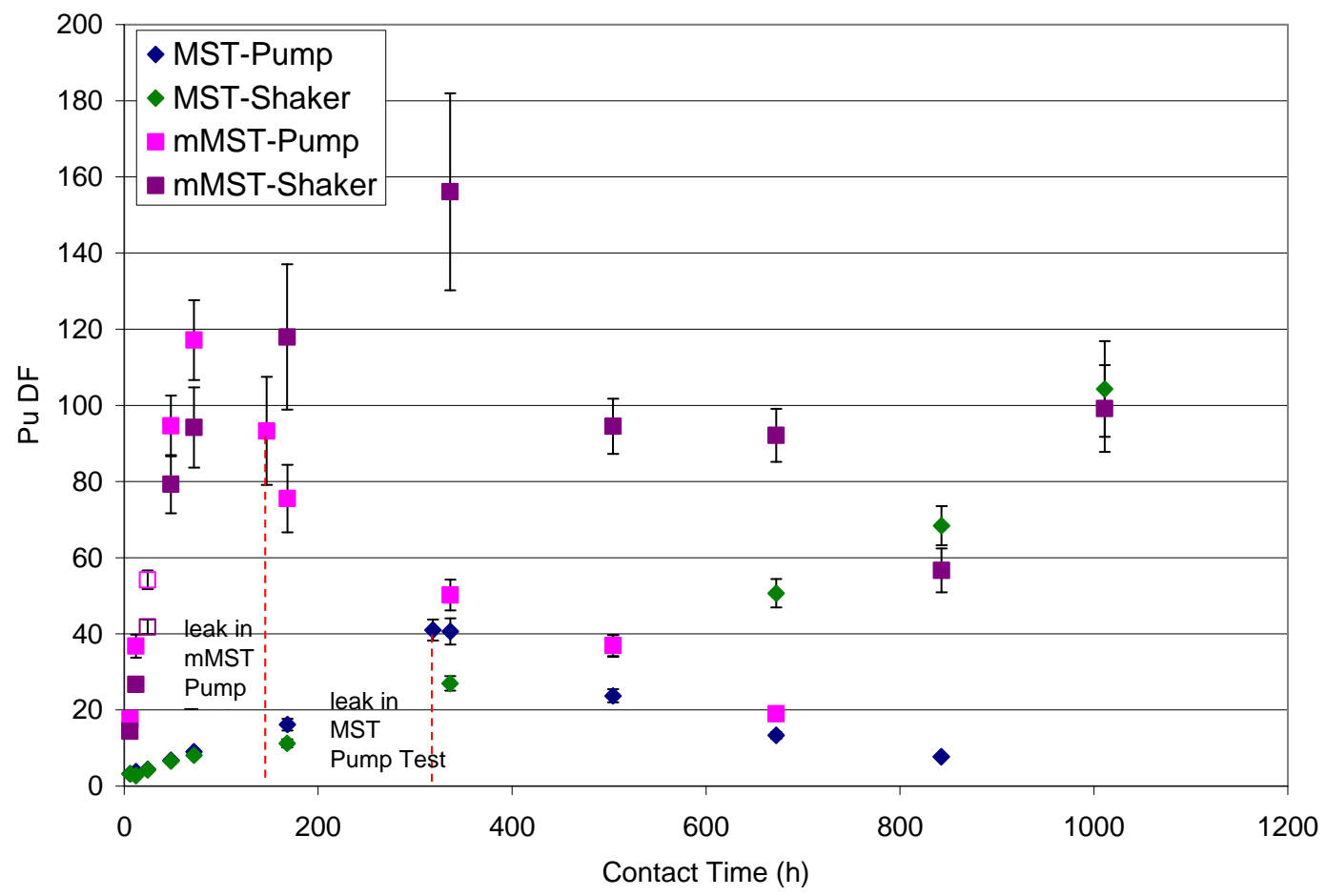

Figure A-2. Pu DF versus contact time. Open data points indicate minimum DF values (i.e., measured concentrations are at detection limits). 
SRNL-STI-2011-00215

Revision 0

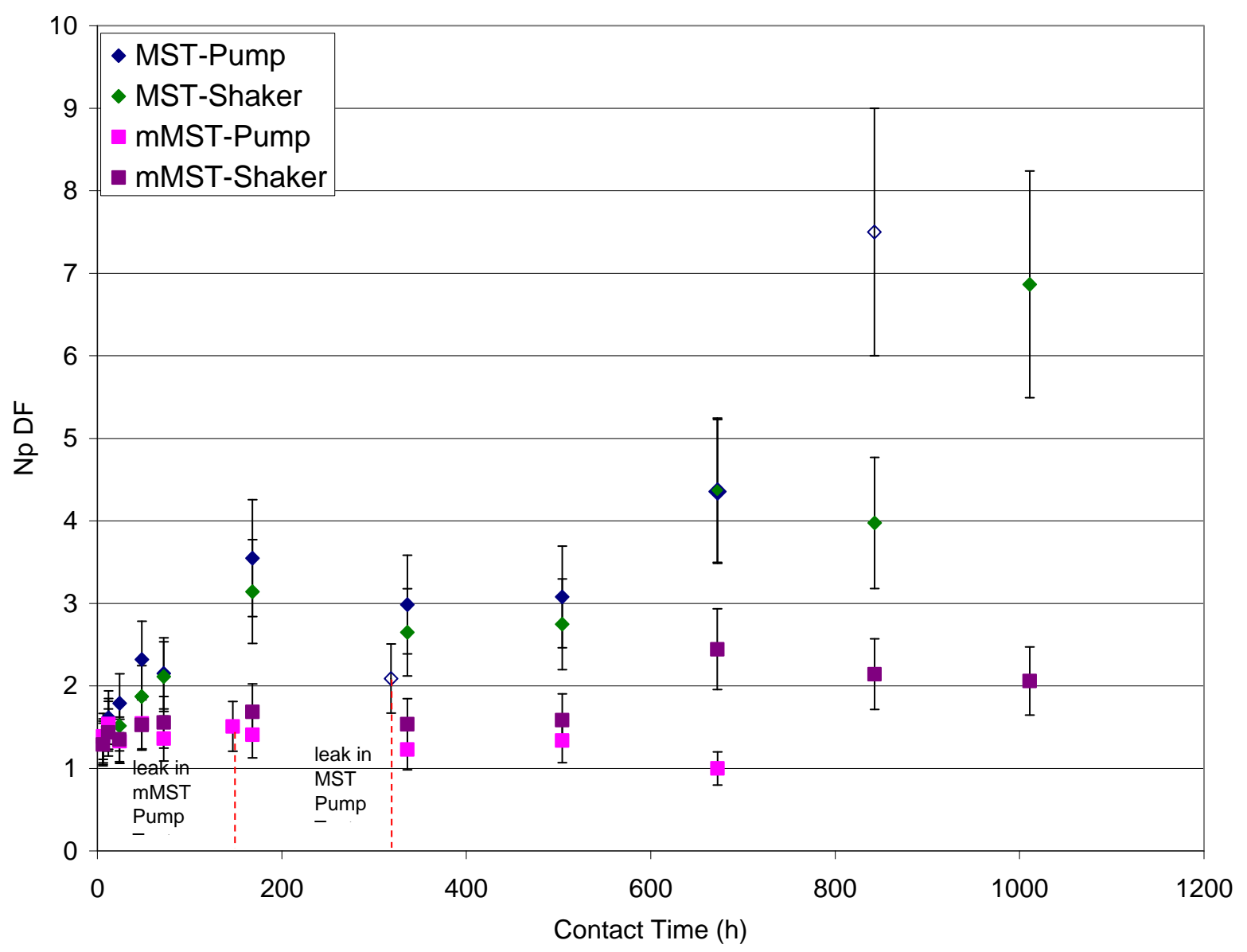

Figure A-3. Np DF versus contact time. Open data points indicate minimum DF values (i.e., measured concentrations are at detection limits). 
SRNL-STI-2011-00215

Revision 0

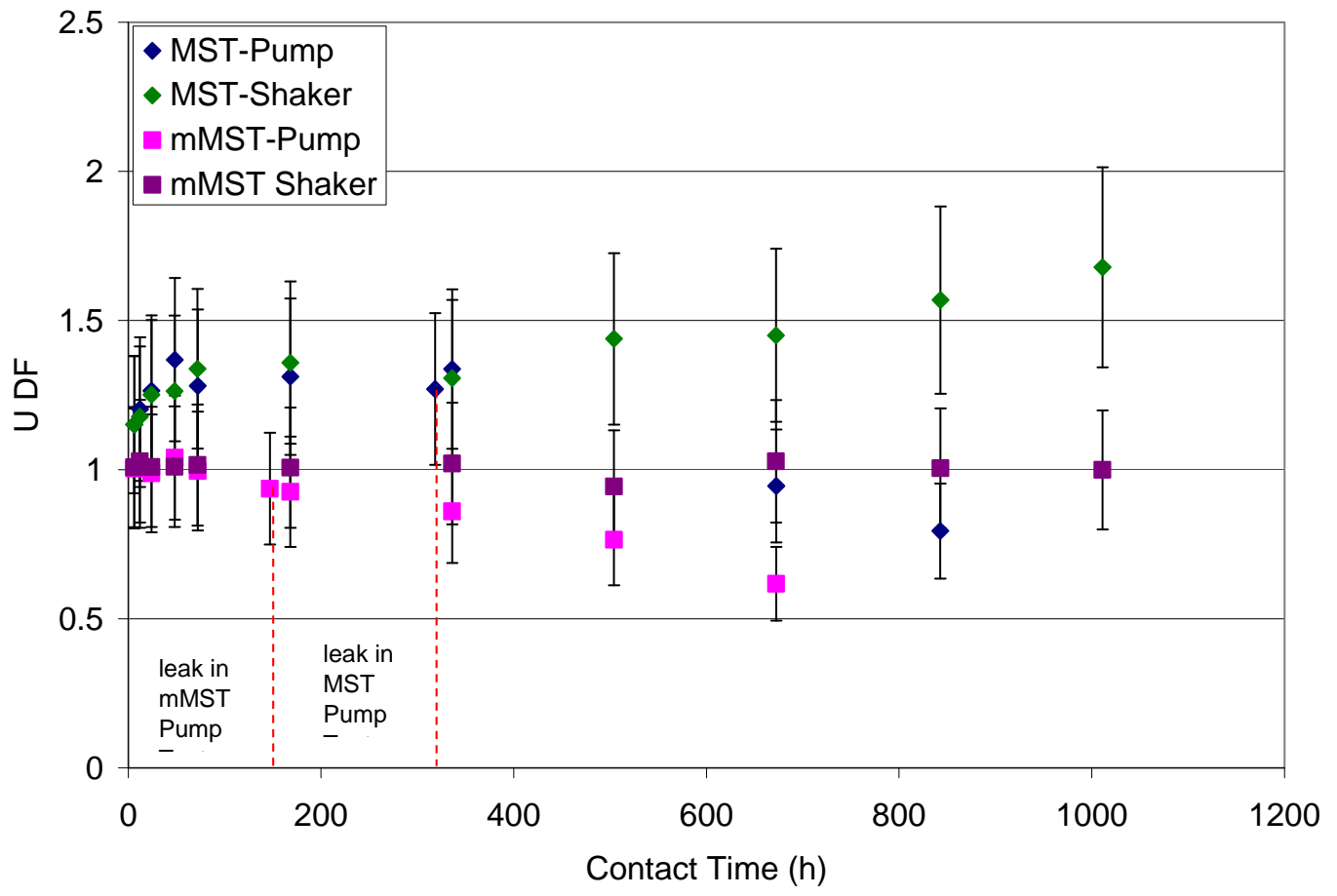

Figure A-4. U DF versus contact time. 


\section{Distribution:}
A. B. Barnes, 999-W
D. A. Crowley, 773-43A
S. D. Fink, 773-A
B. J. Giddings, 786-5A
C. C. Herman, 999-W
S. L. Marra, 773-A
A. M. Murray, 773-A
F. M. Pennebaker, 773-42A
W. R. Wilmarth, 773-A
P. R. Jackson, 703-46A
K. H. Subramanian, 766-H
M. A. Rios-Armstrong, 773-66A
T. H. Huff, 773-66A
R. E. Edwards, 773-67A
M. W. Geeting, 241-152H
K. L. Lang, 704-27S
B. A. Oard, 704-61H 